\title{
Voting on the Budget Deficit: Comment
}

\author{
Ben D. Peletier; Robert A. J. Dur; Otto H. Swank \\ The American Economic Review, Vol. 89, No. 5. (Dec., 1999), pp. 1377-1381.
}

Stable URL:

http://links.jstor.org/sici?sici=0002-8282\%28199912\%2989\%3A5\%3C1377\%3AVOTBDC\%3E2.0.CO\%3B2-G

The American Economic Review is currently published by American Economic Association.

Your use of the JSTOR archive indicates your acceptance of JSTOR's Terms and Conditions of Use, available at

http://www.jstor.org/about/terms.html. JSTOR's Terms and Conditions of Use provides, in part, that unless you have obtained prior permission, you may not download an entire issue of a journal or multiple copies of articles, and you may use content in the JSTOR archive only for your personal, non-commercial use.

Please contact the publisher regarding any further use of this work. Publisher contact information may be obtained at http://www.jstor.org/journals/aea.html.

Each copy of any part of a JSTOR transmission must contain the same copyright notice that appears on the screen or printed page of such transmission.

The JSTOR Archive is a trusted digital repository providing for long-term preservation and access to leading academic journals and scholarly literature from around the world. The Archive is supported by libraries, scholarly societies, publishers, and foundations. It is an initiative of JSTOR, a not-for-profit organization with a mission to help the scholarly community take advantage of advances in technology. For more information regarding JSTOR, please contact support@jstor.org. 


\title{
Voting on the Budget Deficit: Comment
}

\author{
By Ben D. Peletier, Robert A. J. Dur, and Otto H. Swank*
}

During the 1970's and 1980's, many OECD countries have experienced excessively high budget deficits, resulting in a huge increase in government debt. Growing concerns about the effects of high government debt, and the apparent inability of policy makers to make the necessary budgetary adjustments, gave rise to a discussion about the appropriateness of fiscal rules which would constrain fiscally irresponsible policy makers. In the United States, there has been a lively debate on the balanced-budget amendment. In Europe, fiscal rules, restricting the level of the budget deficit and government debt, have been adopted in the Maastricht Treaty, as precondition for the admission of a country to the monetary union. Similar rules have been adopted in the "Stability and Growth Pact." These rules are intended to restrict policy makers in admitted countries to run excessive budget deficits after the start of EMU.

In an influential paper in this Review, Guido Tabellini and Alberto Alesina (1990), henceforth TA, provide an appealing rationale for such fiscal rules. They show that policy makers have an incentive to run an excessively high budget deficit if they are uncertain about future policy makers' preferences over the composition of public spending. The idea behind their result is simple. A budget deficit enables the current policy maker to spend more on goods which she likes, while it limits spending of her successor on goods which she likes less. The strategic interaction between the current policy maker and her successor distorts society's in-

\footnotetext{
* Peletier: J.P. Morgan, Structured Products Group, London, 60 Victoria Embankment, London EC4Y 0JP, United Kingdom (e-mail: Peletier_Ben@JPMorgan.com); Dur and Swank: Tinbergen Institute and Research Centre for Economic Policy (Ocfeb), Erasmus University, P.O. Box 1738, 3000 DR Rotterdam, The Netherlands (e-mail: R.Dur@econ.uu.nl; swank@few.eur.nl).We are grateful to two anonymous referees for useful comments. Financial support by the Erasmus University through Impulsgelden is gratefully acknowledged. The views expressed in this paper are not representative of the views of J.P. Morgan.
}

tertemporal choices. If the budget deficit were chosen behind a "veil of ignorance," policy makers would unanimously choose a lower budget deficit. For this reason, TA plead for institutional arrangements which separate intertemporal choices from decisions concerning the allocation of resources within any given period. Such arrangements would prevent policy makers from running budget deficits for strategic purposes.

Though TA's analysis focuses on budget deficits, the basic idea behind their model can be applied to any other variable which can be used to affect future policies. An obvious candidate is public investment, as public investment today affects future resources. In this Comment we discuss a simple model in which the current policy maker affects her successor's policies by both her choice of the budget deficit and her choice of the level of public investment. In the spirit of the TA model, we assume disagreement between the current and future policy maker about the composition of public consumption. We show that without a binding constraint on the budget deficit, public investment is set at its socially optimal level while the budget deficit is excessively high. A binding rule on the level of the deficit eliminates excessive borrowing, as in TA, but induces the current policy maker to spend too little on public investment. Effectively, by removing one distortion the policy maker is led to create another, possibly more costly, distortion. Consequently, a binding debt rule may be ex ante inefficient. ${ }^{1}$

The analysis is highly relevant for the still ongoing discussion about fiscal rules in Europe and the United States. In a recent paper on the pros and cons of the Stability Pact, Barry Eichengreen and Charles Wyplosz (1998) mention as an objection to a binding debt rule that it

\footnotetext{
${ }^{1}$ Here we adopt TA's terminology: a policy is said to be ex ante efficient if before knowing the preferences of the current policy maker voters consider that policy to be optimal.
} 
suppresses symptoms without curing the disease. However, they conclude: "If excessive deficits can be prevented only by using the EU's authority to impose a credible external constraint, there is no reason not to try." We argue that there is a good reason not to try. An external credible constraint creates another, possibly more costly, distortion. In order to eliminate the political distortions, fiscal rules should apply to all policy areas which may affect future resources. An incomplete set of rules may do more harm than good. A step in the right direction seems to be to add a rule for public investment, or to allow policy makers to borrow for public investment (cf., Nouriel Roubini, 1995). However, the difficulties in precisely defining public investment will render such an additional rule either too strict or too soft. Moreover, there may be still other ways to soften the budget constraint at the expense of future resources, for example spending less on durable public consumption.

Our analysis hinges on the idea that budgetary institutions matter, not only for deficits, but also for public investment. Unfortunately, there exists little direct evidence on the effects of budgetary institutions on public investment. The reason for this lack of evidence is twofold. First, budgetary innovations are scarce and possibly endogenous. Second, cross-national comparisons are hampered by nonbudgetary differences between countries. James M. Poterba (1995) circumvents these problems, at least to some extent, by using the variation in budget practices across U.S. states to examine the effects of budgetary rules on public investment. Consistent with the result of our model, Poterba finds that states which are not allowed to finance capital spending by future revenues spend less on capital goods.

There exists more indirect evidence on the effects of budgetary practices on public investment. Jakob de Haan et al. (1996) find that public investment is often reduced in periods of restrictive fiscal policies and fiscal consolidation (see also Roubini and Jeffrey Sachs, 1989). Alesina and Silvia Ardagna (1998) present data of fiscal and macroeconomic variables around successful and unsuccessful fiscal adjustments in OECD countries for the period 1960-1994. They show that in the two years after a successful adjustment public investment in share of GDP is on average 16 percent lower than in the two years before the adjustment. From the expenditure categories considered (transfers, government wages, nonwages consumption, and government investment) this is by far the largest reduction. To compare, in the two years after a successful adjustment transfers in share of GDP is on average less than 4 percent lower than in the two years before the adjustment. The decline in public investment after a successful fiscal adjustment was even more dramatic in countries which had very high debt levels, presumably the countries which were most biased towards excessive budget deficits. In Belgium, public investment in share of GDP was reduced by 40 percent (1986-1987), in Ireland it was reduced by 29 percent (1985-1986), and in Italy it was reduced by 27 percent (1994-1995). Interestingly, neither in Belgium nor in Ireland public investment in share of GDP has increased after the fiscal adjustments.

It is worth emphasizing that this Comment does not question the importance of TA's analysis. On the contrary, in our model the reason why policy makers may invest too little is essentially the same as the reason why in the TA model policy makers run excessive budget deficits. However, our results do cast doubt on their policy recommendation for institutional arrangements which prevent policy makers from running budget deficits for strategic purposes. Furthermore, our model provides an explanation for the observation that public investment is often reduced in periods of restrictive fiscal policies and fiscal consolidation.

\section{The Augmented Model}

In TA, a group of heterogeneous individuals is endowed with one unit of output per period. The world lasts two periods. In each period the median voter decides on how to spend this endowment on the consumption of two public goods, denoted $g$ and $f$. In period 1 the group can borrow or lend to the rest of the world at a given real interest rate which is assumed to be 0 . In period 2 all the outstanding debt has to be repaid. The median voter of 
the group is characterized by the following utility function:

(1) $W^{m}=E\left\{\sum_{t=1}^{2}\left[\alpha^{m} u\left(g_{t}\right)+\left(1-\alpha^{m}\right) u\left(f_{t}\right)\right]\right\}$

where $E(\cdot)$ is the expectation operator, and $u(\cdot)$ is concave, strictly increasing, twice continuously differentiable, and satisfies the conditions $u(0)=0$ and $u^{\prime}(0) \rightarrow \infty$. An important feature of the model is that the identity of the median voter need not be the same in period 1 and 2. The parameters $\alpha_{1}^{m}$ and $\alpha_{2}^{m}$ identify the median voter in period 1 and period 2, respectively. Both $\alpha_{1}^{m}$ and $\alpha_{2}^{m}$ lie in the interval $[0,1]$.

We augment the TA model by giving the group in period 1 the opportunity to invest an amount of $k_{1}$ which yields additional resources in period 2 of amount $h\left(k_{1}\right)$. To ensure an interior solution, we assume that $h^{\prime}\left(k_{1}\right)>0$ and $h^{\prime \prime}\left(k_{1}\right)<0$, i.e., decreasing returns to investment, and $h^{\prime}(0)>1$. The group faces the following intertemporal budget constraint:

$$
\begin{gathered}
g_{1}+f_{1}+k_{1}=1+h\left(k_{0}\right)+k_{0}+b_{1} \\
g_{2}+f_{2}=1+h\left(k_{1}\right)-b_{1}
\end{gathered}
$$

where $b_{1}$ denotes debt. In equation (2a) $k_{0}$ is the socially optimal amount of public investment [i.e., $h^{\prime}\left(k_{0}\right)=1$ ]. We add $h\left(k_{0}\right)+k_{0}$ to the initial resources to rule out tax smoothing as a reason for running a deficit in period 1. This facilitates an elegant exposition of the results.

Our model differs from the TA model in one respect. In our model there are two ways, rather than one way, in which the current majority can influence the future majority's decisions. Equation (2) clearly reveals that both the amount of public debt and the level of public investment in period 1 have an effect on the size of the future budget.

\section{Equilibrium Without a Balanced-Budget Rule}

In order to ensure a time-consistent policy, we start the analysis with solving the optimiza- tion problem faced by the median voter in period 2:

$$
\max _{g_{2}, f_{2}} \alpha_{2}^{m} u\left(g_{2}\right)+\left(1-\alpha_{2}^{m}\right) u\left(f_{2}\right)
$$

subject to (2b). Substituting (2b) into (3), and maximizing with respect to $g_{2}$, yields the following first-order condition:

$$
\begin{aligned}
& \alpha_{2}^{m} u^{\prime}\left(g_{2}\right)-\left(1-\alpha_{2}^{m}\right) u^{\prime}\left(1+h\left(k_{1}\right)\right. \\
& \left.-b_{1}-g_{2}\right)=0 .
\end{aligned}
$$

Equation (4) and the budget constraint (2b) together implicitly define the equilibrium values $g_{2}^{*}$ and $f_{2}^{*}$ as a function of the preferences of the median voter in period 2 , the level of public debt, and the level of public investment. Denoting these functions as $G\left(\alpha_{2}^{m}, b_{1}, k_{1}\right)$ and $F\left(\alpha_{2}^{m}\right.$, $\left.b_{1}, k_{1}\right)$, respectively, it is straightforward to derive that:

$$
\begin{gathered}
G_{\alpha}=-F_{\alpha}>0 ;-1 \leq G_{b} \leq 0 ; \\
-1 \leq F_{b} \leq 0 ; \\
G_{k}=-h^{\prime}\left(k_{1}\right) G_{b} \geq 0 ; F_{k}=-h^{\prime}\left(k_{1}\right) F_{b} \geq 0
\end{gathered}
$$

where subscripts denote partial derivatives.

The median voter in period 1 takes into account the effect of her choice of $b_{1}$ and $k_{1}$ on the decisions made by the median voter in period 2 . Using (2a), the optimization problem can be written as:

$$
\text { (6) } \begin{aligned}
\max _{g_{1}, b_{1}, k_{1}} & \alpha_{1}^{m} u\left(g_{1}\right)+\left(1-\alpha_{1}^{m}\right) u\left(1+h\left(k_{0}\right)\right. \\
& \left.+k_{0}+b_{1}-k_{1}-g_{1}\right) \\
& +E\left[\alpha_{1}^{m} u\left(G\left(\alpha_{2}^{m}, b_{1}, k_{1}\right)\right)\right. \\
& \left.+\left(1-\alpha_{1}^{m}\right) u\left(F\left(\alpha_{2}^{m}, b_{1}, k_{1}\right)\right)\right] .
\end{aligned}
$$

Since the identity of the median voter in period 2 is uncertain, the expectation operator in (6) is taken with respect to $\alpha_{2}^{m}$. The first-order conditions are: 
(7)

$$
\begin{gathered}
\alpha_{1}^{m} u^{\prime}\left(g_{1}\right)-\left(1-\alpha_{1}^{m}\right) u^{\prime}\left(1+h\left(k_{0}\right)\right. \\
\left.+k_{0}+b_{1}-k_{1}-g_{1}\right)=0
\end{gathered}
$$

$$
\begin{aligned}
& \alpha_{1}^{m} u^{\prime}\left(g_{1}\right)+E\left[\alpha_{1}^{m} u^{\prime}\left(G\left(\alpha_{2}^{m}, b_{1}, k_{1}\right)\right) G_{b}\right. \\
& \left.+\left(1-\alpha_{1}^{m}\right) u^{\prime}\left(F\left(\alpha_{2}^{m}, b_{1}, k_{1}\right)\right) F_{b}\right]=0
\end{aligned}
$$

$$
\begin{aligned}
& -E\left[\alpha_{1}^{m} u^{\prime}\left(G\left(\alpha_{2}^{m}, b_{1}, k_{1}\right)\right) G_{b} h^{\prime}\left(k_{1}\right)\right. \\
& \left.+\left(1-\alpha_{1}^{m}\right) u^{\prime}\left(F\left(\alpha_{2}^{m}, b_{1}, k_{1}\right)\right) F_{b} h^{\prime}\left(k_{1}\right)\right]=0
\end{aligned}
$$

where we have used $G_{k}=-h^{\prime}\left(k_{1}\right) G_{b}$ and $F_{k}=-h^{\prime}\left(k_{1}\right) F_{b}$ [see equation (5)]. From equations (8) and (9) it directly follows that $h^{\prime}\left(k_{1}\right)=1$. Hence, public investment is set at its socially optimal level. Public debt is then determined by the solution to equations (7) and (8), which are similar to the first-order conditions (5) and (6) in the original TA model. Hence, all their results hold in the augmented model. In particular, (7) and (8) imply that if there is a positive probability that $\alpha_{2}^{m} \neq \alpha_{1}^{m}$, the median voter will run an excessively high budget deficit. Moreover, the optimal level of the deficit increases with the difference between $\alpha_{1}^{m}$ and the expected value of $\alpha_{2}^{m}$. Thus, the more polarized are the current and future majorities, the higher is the level of the budget deficit. A balanced budget is chosen when there is no disagreement between the current and the future majority (i.e., $\alpha_{2}^{m}=\alpha_{1}^{m}$ with certainty). Hence, as in TA, budget deficits only arise for strategic reasons.

Interestingly, in the discretionary equilibrium public investment is not used strategically. The intuition is straightforward. The median voter in period 1 can soften its budget constraint at the expense of future resources in two ways: by running a budget deficit and by reducing public investment to a level below the socially optimal level. While running a budget deficit reduces resources in period 2 proportionally, lowering public investment affects future resources more than proportionally since $h^{\prime}\left(k_{1}\right)>1$ for values of $k_{1}$ below the socially optimal amount. Hence, with complete discretion over the level of the deficit, the median voter will not use public investment strategically.

\section{Consequences of a Balanced-Budget Rule}

We now turn to the second main result of TA: a balanced-budget rule is ex ante efficient. ${ }^{2}$ This result is, however, obtained in a model without public investment. We will now analyze what happens if public investment is included.

When a balanced-budget rule is imposed (implying $b_{1}=0$ ), first-order condition (8) no longer holds. Only first-order conditions (7) and (9) remain. Given that a positive level of debt is optimal in the discretionary equilibrium, under a balanced-budget rule we have that the expression in (8) is positive (i.e., the marginal benefit of higher public debt exceeds marginal costs). Knowing this, it is easy to see that condition (9) requires $h^{\prime}\left(k_{1}\right)>1$. Hence, a balanced-budget rule induces the median voter to invest too little.

Clearly, a balanced-budget rule does not solve the problem of intertemporal strategic behavior. In order to reach the ex ante efficient state, an additional rule for the level of investment has to be implemented. Unfortunately, such a solution poses at least three new problems. First, there is the problem of determining the optimal level of investment. Obviously, our model is far too simple for such a task. But even in a more general setting, it will not be easy to find a reliable estimate of the optimal investment level, particularly when that level changes over time. ${ }^{3}$ The second problem is that public investment exists in widely varying forms, of which some are not easily quantifiable. A wellknown example is investment in human capital. Finally, and perhaps most importantly, once a balanced-budget rule and a public investment rule are imposed, governments will seek alternative ways to soften their own budget constraint. For example, when durable expenditures are introduced into our model on which all individuals agree, a balanced-budget rule and an investment rule induce governments to spend

\footnotetext{
${ }^{2}$ TA do, however, stress an important downside of a balanced-budget rule: the fact that it greatly reduces the flexibility with which to respond to unexpected shocks. Our point is that even in the absence of such shocks, or with a state-contingent budget rule, a balanced-budget rule will have a negative effect, namely underinvestment.

${ }^{3}$ The "Golden Rule of Government Finance" (i.e., the permitted level of the budget deficit is equal to the level of public investment) may overcome this problem. See Chapter 2 in Dur (2000).
} 
too little on durable consumption goods (Peletier et al., 1997).

Even if it is not immediately possible to reach the ex ante efficient state, the question remains whether a balanced-budget rule, or an incomplete set of rules, is preferable to no rule at all? As it turns out, the answer is no, not in general. In Peletier et al. (1997) simulations are presented which show that it can go both ways: in some cases, a balanced-budget rule increases ex ante utility, whereas in other cases, it lowers it. This essentially reflects the fact that a balanced-budget rule has two opposing effects: first, it takes away an instrument that is used to increase current spending relative to future spending. This, ceteris paribus, raises ex ante utility, as all voters ex ante would prefer spending to be smoothed over both periods. Second, it causes public investment in period 1 to drop. This, ceteris paribus, lowers utility, as voters ex ante would prefer a higher level of investment in that period. Which of these two effects dominates depends on the exact specification of the utility functions.

\section{Conclusion}

In this Comment, we have argued that a balanced-budget rule may cause underinvestment. As a consequence, such a rule is not $e x$ ante efficient: in order to achieve the ex ante optimal outcome, it would be necessary to add an extra rule for the level of public investment. Unfortunately, however, such an investment rule is likely to be very difficult to implement in practice. When there are no rules to prevent underinvestment, it is no longer clear whether a balanced-budget rule is beneficial or not. In some cases, the costs of low levels of investment outweigh the benefits of a balanced budget.

\section{REFERENCES}

Alesina, Alberto and Ardagna, Silvia. "Tales of Fiscal Adjustment.” Economic Policy, October 1998, 13(27), pp. 487-545.

de Haan, Jakob; Sturm, Jan Egbert and Sikken, Bernd Jan. "Government Capital Formation: Explaining the Decline." Weltwirtschaftliches Archiv, 1996, 132(1), pp. 55-74.

Dur, Robert A. J. "Political Institutions and Economic Policy Choice." Ph.D. dissertation, Tinbergen Institute, Rotterdam, 2000 (forthcoming).

Eichengreen, Barry and Wyplosz, Charles. "The Stability Pact: More than a Minor Nuisance?" Economic Policy, April 1998, 13(26), pp. 65-104.

Peletier, Ben D.; Dur, Robert A. J. and Swank, Otto H. "Voting on the Budget Deficit: Comment." Mimeo, Erasmus University, Rotterdam, September 1997.

Poterba, James M. "Capital Budgets, Borrowing Rules, and State Capital Spending." Journal of Public Economics, February 1995, 56(2), pp. 165-87.

Roubini, Nouriel. "The Economics of Fiscal Bondage: The Balanced Budget Amendment and Other Binding Fiscal Rules." Mimeo, New York University, June 1995.

Roubini, Nouriel and Sachs, Jeffrey. "Government Spending and Budget Deficits in the Industrial Countries." Economic Policy, April 1989, (8), pp. 99-132.

Tabellini, Guido and Alesina, Alberto. "Voting on the Budget Deficit." American Economic Review, March 1990, 80(1), pp. 37-49. 
http://www.jstor.org

\section{LINKED CITATIONS \\ - Page 1 of 1 -}

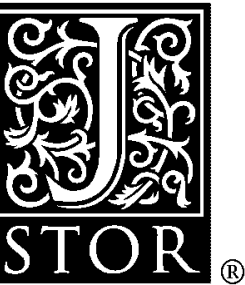

You have printed the following article:

\section{Voting on the Budget Deficit: Comment}

Ben D. Peletier; Robert A. J. Dur; Otto H. Swank

The American Economic Review, Vol. 89, No. 5. (Dec., 1999), pp. 1377-1381.

Stable URL:

http://links.jstor.org/sici?sici=0002-8282\%28199912\%2989\%3A5\%3C1377\%3AVOTBDC\%3E2.0.CO\%3B2-G

This article references the following linked citations. If you are trying to access articles from an off-campus location, you may be required to first logon via your library web site to access JSTOR. Please visit your library's website or contact a librarian to learn about options for remote access to JSTOR.

\section{References}

\section{Tales of Fiscal Adjustment}

Alberto Alesina; Silvia Ardagna; Jordi Galí

Economic Policy, Vol. 13, No. 27. (Oct., 1998), pp. 487-545.

Stable URL:

http://links.jstor.org/sici?sici=0266-4658\%28199810\%2913\%3A27\%3C487\%3ATOFA\%3E2.0.CO\%3B2-V

\section{The Stability Pact: More than a Minor Nuisance?}

Barry Eichengreen; Charles Wyplosz; Charles Bean; Stefan Gerlach

Economic Policy, Vol. 13, No. 26, EMU. (Apr., 1998), pp. 65-113.

Stable URL:

http://links.jstor.org/sici?sici=0266-4658\%28199804\%2913\%3A26\%3C65\%3ATSPMTA\%3E2.0.CO\%3B2-F

\section{Government Spending and Budget Deficits in the Industrial Countries}

Nouriel Roubini; Jeffrey Sachs; Seppo Honkapohja; Daniel Cohen

Economic Policy, Vol. 4, No. 8. (Apr., 1989), pp. 99-132.

Stable URL:

http://links.jstor.org/sici?sici=0266-4658\%28198904\%294\%3A8\%3C99\%3AGSABDI\%3E2.0.CO\%3B2-4

\section{Voting on the Budget Deficit}

Guido Tabellini; Alberto Alesina

The American Economic Review, Vol. 80, No. 1. (Mar., 1990), pp. 37-49.

Stable URL:

http://links.jstor.org/sici?sici=0002-8282\%28199003\%2980\%3A1\%3C37\%3AVOTBD\%3E2.0.CO\%3B2-R 